\title{
The University's Role in Promoting its Students' Social Awareness from the Students' Perspective at Balqa Applied University
}

\author{
Mallouh Mufdi Barakat Slaihate ${ }^{1, *}$ \\ ${ }^{1}$ Department of Foundation of Education, Al-Balqa' Applied University (BAU), Al-Salt \\ 19117, Jordan
}

*Correspondence: Department of Foundation of Education, Princess Rahma University College, AlBalqa' Applied University/ P.O. Box: Al-Salt 19117, Jordan. E-mail: mallouh_abady@yahoo.com

This work has been carried out sabbatical leave granted to the author Mallouh Al-Slaihate from Al-Balqa' Applied University (BAU) during the academic year 2013/2014

Received: August 16, 2014 Accepted: October 31, 2014 Published: December 7, 2014

doi:10.5296/ije.v6i4.6744 URL: http://dx.doi.org/10.5296/ije.v6i4.6744

\begin{abstract}
This study aimed to investigate the university's role in promoting social awareness of Balqa Applied University's students from the perspective of the students themselves, and to identify the impact of some demographic variables as gender, type of college and the academic year on this role. To achieve the study's objectives, the researcher presented a conceptual frame about the students' social awareness and the university's role in this awareness, and applied a field study on Al-balqa Applied University's students in three colleges that represented Jordan's three provinces. The questionnaire which consisted of 37 items was distributed into three fields, and applied after checking its acceptable degree of reliability and validity. Data were analyzed using the appropriate statistical tests.

The results revealed that the university's role in promoting the students' social awareness was high in the field of the academic staff's role, while it was moderate in the fields of the university and curriculum, and methods of teaching plus evaluation' roles, and in the total degree of the instrument as well. The results also revealed that there were no statistically significant differences attributed to the gender and faculty's variables, whereas the academic year variable was statistically significant, and the differences were in favour of the freshmen students in the field of university administration, and the fourth year students in the field of academic staff's role. Based on these results, the study recommended the necessity to reconsider the roles of university, curriculum, and methods of teaching and evaluation in promoting the social awareness by preparing programs which promote the social awareness, and to design university courses that enrich the students' humanistic knowledge in different fields that suits their social status.
\end{abstract}

Keywords: social awareness, universities 


\section{Introduction}

Preparing and rehabilitating the human resources is considered one of the universities' major goals, and the universities seek to achieve the ideal preparation of human resources, so as to enable them work in all the fields which the society need. And to achieve this goal, the universities coordinate with the society's different institutions to provide the components of youth care with all of its mental, psychological, social and psychical aspects, and anything that can help in launching the youth's capabilities in different fields at the same time.

The youth category in the young societies, as the Jordanian one, is considered the most precious wealth of society for its flexibility in dealing with life's rapid changes, its efficiency in taking social responsibility, and its expected role in serving the society. Literature points out that the youth forms the highest numeral part in the developing countries, and it is the most sensitive category socially in terms of its situation attitude and destiny, but at the same time this category is considered the most attractive one to the crises, and the most affected by the modern changes, so developing the youth social awareness is seen as an urgent and necessary need, especially, in light of their life's deterioration, and their neutrality towards society's issues. (Al-asad, 2011)

Awareness is defined as the realization of issues in general and into details, and this realization is based on intellectual background and scientific basis, so it is a state of mind represented in the individual's realization of the world mentally or emotionally. Therefore, human awareness is represented through different images that vary according to the perceived field, or the subject of the awareness. The human knows different types of awareness as social awareness, and what it includes as ethical, religious and political awareness. Based on what is mentioned previously, human is distinguished by awareness. The individuals know two kinds of awareness; the positive awareness and the negative one or the fake one. The positive awareness is the positive, constructive, and logical thought, and it guides the society towards what is useful; causing the appearance of a huge human power that can be employed. While the negative or fake awareness is the individual interest of a specific category; and it means rejection and ignorance, consciously or unconsciously, of other categories' demands so a wrong perspective of reality is created. Therefore, it should be stated that if fake awareness addressed consenting in a social environment through an authority, it would be required the same degree of real awareness, even the mutual consenting gives legitimacy that exceeds real awareness, which did not achieve the condition of satisfaction although satisfaction could be a result of promotion or ignorance of hidden obligation. (Makroom, 2009)

\section{Theoretical Frame}

Awareness, in human life, has positive relation with science and knowledge, so whenever the individual's awareness increases, it means possessing science and knowledge. Awareness has no limits or borders, and the individual keeps moving on. So the more the individual cares of awareness, the more the awareness is developed and increased, and if the individual neglects 
awareness, it will shrink. Therefore, it was mentioned that awareness with its cognitive perspectives reforms human life according to a new system, transferring the individual from limited status into the world of creativity and independence, and thiswhat the Arab World needs. Developing the individual in Arab World is considered a great change, because awareness is a necessary condition for possessing moral, intellectual and material capabilities, and the positive interaction with many important issues which modern Arab people need. (Al-Haj, 2000)

Marxism is the first one who used the social awareness' idiom, which means the individual's self-realization as a member in a group, and the ability of understanding others' feelings and the society interactions, and employs them to be social creatures and understand social habits and traditions, in order to facilitate the individual integration in the society. In other words, social awareness enables the individual to see the society and its problems from a comprehensive view, and be effective in this society based on his social awareness. (Al-hafni, 2010)

It is illustrated from what was mentioned previously that there is an argumentative relation between social awareness and the social existence. And because the sociologists differed in identifying the nature of this relation between, two trends appeared; ideal doctrine which believes that awareness specifies the existence. While the owners of materialism believe that the individuals' existence identifies their social awareness, which indicates that their social awareness follows the social existence, the social existence is the basis upon which the social awareness is built. (Abdel latif, 2005)

The Psychological and intellectual components are considered the most important components in the society, which they belong to whether their behavior expresses their satisfaction, or rejection to this society or the compatibility with it. While the intellectual component represents science, theories, knowledge, beliefs, ideas and concepts that supply people with the intellectual activity, and it helps the individuals to understand the social status; it provides the individual with the ability to think, and search for possible solutions for social problems facing them, but these problems are restricted by the availability of freedom and democracy, and not being exposed to internal and external pressures that affect their thought movement and interaction with other members of the society. (Al-rashdan, 2004)

And this explained the low degree of social awareness, and its difference from one person to another, and from a society to another; because of the differences in the individuals' and societies' understanding of the social awareness' components. This awareness, which is not solid, can be developed and renewed if reasons for this development are available. Education and social upbringing are considered the most important reasons. The social awareness is changed and developed from time to another; as a result to what the individual or the society is exposed to, because status and awareness are both movable. So, according to this development and the continuous change, we still need eagerly to a constructive criticism that supports this awareness, and supplies it with new vision to have a social transformation that aimed at achieving social progress and development. (Salim, 1999)

The individuals' social awareness is formed through the social upbringing, and through other 
institutions as the family, the school, the higher education and the society. The purpose of these processes is to understand and realize the social status which the individual belongs to, and to find possible solutions to the modern social issues and problems. The higher education has a great importance in this field because universities lie in the last educational level before the individual's access into the field of work. The youth, at this level, are characterized by maturation, realization and awareness, but this does not indicate that they all are equal in their social awareness, because there are many variables that control this awareness. One of these variables is the individuals' rank in the society, and the nature of the society whether it is rural, or urban or Bedouin. The content of the educational system and its attitudes and all the values and moral standards, the content of the official media, and its role in justifying the social situations in that society, in addition to the work's circumstances. (Nassir, 2004)

It was previously mentioned that social awareness is the individual's over all of the society issues concerning the life of the individual and the society, and because these issues varied politically, religious, culturally, legally and other types of issues. The social awareness has many types according to the variety of the society issues which it discussed. Political awareness is defined as the general understanding of the political atmosphere and the interactions and plans of the politicians whether they are inside or outside the country, because of the international correlation of the events. The concept of political awareness is connected with the individuals, organizations and the societies.

The political awareness is seen as the individual's realization of his responsibilities on intellectual and scientific basis, so he is aware of the events that happened around, and he is able to evaluate them properly, and later this understanding is changed into appropriate, practical and realistic behavior. The individual who is politically conscious knows his rights and duties and, practice them effectively. (Nizar, 2005). The universities and other society institutions can activate the youth political awareness, so as to be more qualified for their current and future situation, and to help them adopting the scientific approach and giving the public interests the priority.

The cultural awareness is seen as "the awareness that enables the individual to see the society and its issues from comprehensive historical perspective", so he has to analyze these issues .If the individuals do not have cultural awareness, they will be unable to face the cultural invasion which dominates, strongly, the Nation's thought and culture trying to distort its culture and replace his culture instead. (Abdel wahab, 2003). So here lie the universities' roles which have the responsibility in promoting the students' cultural awareness, since they are considered the first line of defense in facing these challenges. And the educational institutions would be unable to form a character that is integrated socially, politically, ethically and healthy unless they developed the individuals' social awareness, because it is considered as the comprehensive one which includes the other types of awareness.

Religion is defined as "an intellectual and behavioral system shared by group of individuals where it guides their behavior and the individuals' relation with religion differs", so if the relation was high, their transactions were according to the society's perspectives, which are the perspectives of religion, which means that the individuals' degree of religious' awareness 
has an impact on the society, so the higher the degree is, the society will be more stronger and secure. (Ameen, 2008). The educational institutions are responsible for forming the correct religious thought of their students, which lead to the individuals' awareness of the commitment's importance of religion, and its role in improving the students' behaviors and their relations with the society and its members as well.

The ethical awareness has a strong relation with religious awareness, and it reflects the rules which are applied by the individuals and the groups in their personal and social life. It looks as a mental expression of the importance and necessity of linking the personal interests with the public ones. So the wrong mental awareness caused a wrong ethical awareness where it becomes impossible to distinguish between good and evil. The ethical awareness may get frustrated, so it will lose its strength and be a victim to a kind of awareness characterized by desperation and powerlessness. (Al-tai, 2002)

And in light of the values' conflict, which the world witnesses these days, resulted of attitudes' conflict and the different ideas that threaten the society's high value system, and the values that appeared which do not compatible with Arab society's culture and values, so the educational institutions should play their role in forming the ethical awareness as it is considered one of the most important aims of education, and they should also strengthen the relation between the knowledge and science in one side, and the ethics on the other side. So, if the knowledge and science were without ethics, definitely ethical crises will be appearing, and then knowledge and science will be useless.

The health security means "protecting the citizen and ensuring his safety from diseases and epidemics that threaten his safety". And achieving health security is considered one of the luxury's priorities that developed societies seek to have. Therefore, achieving health security requires providing cultural health and health awareness. The cultural health means "providing health information and facts concerning health and diseases of the individuals". While health awareness means "individual's overall of health's information and facts with the feeling of responsibility towards his health and others', recognizing different diseases and methods of prevention and treatment, and working hard in avoiding them". (Jasim, 2005). So the educational institutions should play its role in this fieldthrough making the students aware of their health, identifying the health problems and ways of treating them, and providing regulations and healthy tips.

The legal awareness means that "the individual knows his rights and duties in all aspects and fields of life and applies this awareness in his daily life". And there is a strong relation between realizing these rights and duties and the practical practice of them. Some people understand their rights and duties but they do not practice them, whereas others do not practice these rights and duties for their ignorance of them, so the output in both cases is having negative people who do not participate in developing the society. (Al-hussami, 2010). So the importance of legal awareness arose since it is considered one of the social awareness component, and the youth category is considered one of the more capable categories in giving and work, so this category should be aware of this field, in order to have their rights and duties kept and protected, so they will be positive individuals in their society. 
The function of education is to transfer the social and cultural heritage, and it has great influence on the individual even education is used as a power for change. Education has many shapes as family education, school education till the university one. Education with its different levels participates effectively in forming and developing social awareness with its all types and shapes, so if the individual is capable of acquiring skills, he is able to have a social awareness of the social problems. (Zeitoon, 1995)

Education can form the students' social awareness through the curricula and methods of teaching. Education designs curricula which are socially useful, and the most important standard used to judge the curricula is to what extent it is socially useful. Education works on updating its curricula to be compatible with the requirements of present and future, and find more innovative methods of teaching that help the students facing their problems through teaching them solving problems' method. The curricula should be practical that do not depend on drilling and memorization, so as not to enlarge the gap between the status and hope, and this explained the failure of many educational policies in the developing countries, and their failure also in achieving their objectives, and forming international social awareness that can interact within the society and with other societies. (Al-sheikh \& Sleibi, 1996). So, re-forming the students' social awareness requires reconsidering all of the educational policies, curriculum, and methods of teaching. We really need a comprehensive development to achieve the compatibility and the harmony between education and the society's needs, then we try our best to change the status to the best. (Christine and Smith, 2010)

It is required from the universities to have a clear role in developing the students' social awareness; in order to enable them behave well in different situations, interact with the problems and issues that their social reality imposed, and to supply them with virtues which make a good man. The university has to have a role in correcting the common wrong values in the society, and this role is one of the most important universities' roles. The real value of science and knowledge is identified out of the universities' scope, so there is a need to widen the universities' educational range to include the whole society, and to work on solving its problems using knowledge and science. (Prasolova, 2002). Therefore, if the universities want to own this efficiency in forming the human character which is able to interact and participate, they should adopt educational policies, programs and activities which can help the students face challenges from time to another. These universities need to change the content of the its courses to enable them to build the human intellectually, politically, socially and culturally, and to have a role in facing challenges of globalization, technology revolution, population and the international competition. (Kathlyn, 2011.

Developing the students' social awareness is done through the sciences and knowledge that the university presented to its students, and by the different relations results of the interaction between the students themselves, and the students and different human and physical input at the university. In other words, social awareness is a reflection to the social relations which are formed during the process of interaction between the cultures and policies that happened in the society. So, social awareness started to be realizing, knowing, and understanding one's self as a member in the society. The basic goal of the processes of forming the university students' social awareness to widen their social perspective by realizing having a great role in 
making a social change in his social structure, and to develop students' characters to be able to interact with other members in the society, in order to deal with problems and challenges facing the society, and to behave rationally in different situations and problems facing them in the fields of life. The role of the university in developing the students' social awareness becomes more important day after a day, so there was a necessity that universities should develop their performance, and increase their students' efficiency according the variation of the society's demands; locally and internationally, through activating the students' role in dealing with their social status, and facing different challenges that stop their civilized progress. Therefore, this study tried to identify the universities' role in promoting the Jordanian universities' students' social awareness represented by Balqa Applied University, and to identify the effect of some variables in the students' social awareness.

\section{Problem of the Study \& Its Questions:}

The problem of the study is represented through answering the following two questions:

1- What is the University role in promoting the social awareness' content of Balqa Applied University's students from the perspective of the students themselves?

2- Does the university's role differs in promoting the social awareness of the students according to the variables of gender, type of college, and the academic years?

\section{Significance of the Study}

The importance of this study lies in the following: the issue it addressed which is the social awareness, the population of the study which is the youth category, and the tool of the study which was developed for the purpose of this study. So, the researcher hopes that the results of this study be helpful to decision makers of the educational policies by the information it provided on the students' social awareness, and the identification of reality, and the imagination of what can be done, and taking the appropriate decisions concerning this. Also the researcher hopes the academic staff's members in the Jordanian and Arab universities get benefit of the study's results through rethinking of their roles and responsibilities in forming the youth social awareness.

\section{Procedural Terms}

Social awareness: it is the society's individuals' overall of the social, political, economic, healthy, religious, ethical, legal and scientific issues that affect their life. 


\section{Limitations of the Study}

- This study is limited to a sample of students at Balqa Applied University in the first semester for the academic year 2013-2014.

- Results of this study depend on degree of the study's tool's reliability and validity, and on the respondents' degree of being series in answering the questionnaire's questions.

\section{Previous Studies}

The study of Watfa (2000) aimed to identify the degree of social awareness of the Kuwait University's students, and the impact of the historical challenges on this awareness, and how Kuwaiti students look at the positive social values. The study revealed that the most significant challenges facing the Kuwaiti society were intolerance, discrimination and racism, economic and technological backwardness, and the absence of comprehensive and fair peace. The sex variable was significant and the differences were in favor of the females who were more interested in the discussed issues.

The study of Prasolova (2002) investigated the degree of awareness of Manchester University's students in Britain. The study surveyed the students' opinions by asking many questions about the students' degree of realizing social awareness, and university activities that support their social awareness. The results of the study revealed that the students' degree of realizing the importance of social awareness is very high, and they assured that that computer labs and social interaction are the best places for acquiring experience. They all agree that good education is the best mechanism to achieve social awareness.

And Lodge (2003) conducted a study in India to measure the students' degree of social awareness, and the extent of their understanding to their social problems, and to identify the degree of the educational system's ability in that region; in order to find possible solutions to the students' social problems. The results showed that school curricula do not discussed the social issues and problems that the students from. The students also expressed their satisfaction towards the cultural activities presented to them, and their dissatisfaction towards the amount of social activities presented to them, and most of the students showed their need to have effective treatment to their social problems.

The study of Abdel Mo'ti(2004) addressed education and social awareness' counterfeiting through surveying the content of the school curricula; in order to identify if education has any role in the students' social awareness' counterfeiting. The results showed that educational system in Egyptis responsible forsocial backwardness, and so it was considered as of the obstacles facing social development, for example, the relation between man and woman. And education built barriers between the students and their realization of reality giving no real explanations, therefore it counterfeit students' awareness.

Hawamda's study (2005) also explored the reasons and the effects of social alienation at the Jordanian universities' students. The results revealed that the most significant reasons of 
alienation were difficulty of their integration, because of the loss of standards, social alienation and lack of affiliation in general. And one of the most important aspects of this social alienation is isolation and withdrawal for their lack of ability in understanding what goes around them. Therefore, they are unable to influence on the surrounded events, in addition to the negative relation between them and the members of the academic staff, and the weakness of the students' activities and their limitation.

Tantawi (2006) conducted a study to identify the nature of the political and social awareness of Zaqaziq University's students in Egypt. And the study aimed to identify the degree of the students' understanding the status of the political and social life in Egypt. The results showed the students' high degree of awareness of the importance of participating in all the political and social issues, and the results also showed importance of sharing of Arab issues and Egypt relations with Arab countries. The variables were not statistically significant.

Lweis's study (2007) investigated the universities' role in preparing the students socially from the students and the academic staff's perspective in public American University. The study aimed at identifying the students and the academic staff's views concerning the best circumstances that should be available, in order to achieve social awareness. The results revealed that all the students and their teachers agreed that university did not pay attention to develop the moral standards, and did not care of its job in this field. And the students considered the most university's most important goals should be respectively as follows: providing them with experiences that deepen their vision to life, and its problems first, and then provide professional training to help them doing their work.

And the study of Rianna (2008) aimed to identify the social awareness skills of American schools' students; to reveal the mechanism of developing the students' social awareness skills to anyone who deals with the students as parents and teachers. The researcher illustrated this during his work as a teacher. The results of the study assured the importance of the students' respect of themselves, and enhanced this respect through behaving properly with them in different situations and places. So, the students' self-confidence and their respect to other will be increased, and that what make the researcher considered this skill as the most important skill, which the students need so as to be diplomatic in their dealing and interacting with the others.

\section{Comment of Previous Studies}

Although of the importance of this study's subject and the importance of the universities' role in promoting its students' social awareness, the number of the studies which discussed this issue is very few. And by surveying summaries of these studies, we noticed that these studies addressed the issue of social awareness, and the degree of different samples' possession of the social awareness' skills, and the impact of this on a number of variables as gender and academic level. The tools of the studies varied; some adapted the questionnaire, and others used analysis, surveying and notices.

This study agreed with the previous studies in addressing the issue of university students' 
social awareness, and in adapting the questionnaire as a tool of the study. While this study differs from the previous studies in choosing the sample which was students of Balqa Applied University, and in revealing the impact of gender, college and academic year variables on this awareness, this study is considered the first one that discusses the social awareness content of the universities Jordanian students represented by the students of Balqa Applied University. Also, this study also differs from previous studies in developing the tool of the study which is consisted of (37) items distributed into three fields: university management, academic staff member, curricula and methods of teaching and evaluation.

\section{Method \& Procedures}

This part addressed the methodology of the study, its population and the sample, its tool and the validity and reliability which it achieved, variables of the study and the statistical treatment.

\subsection{Methodology of the study}

This study followed the analytic descriptive approach to achieve the objectives of this study.

\subsection{Populations of the study and its sample}

The population of the study consisted of 13449 students, representing Al-Balqa Applied University's students in the first semester of the academic year ( 2013-2014), in three colleges which are Al-Balqa Applied University/ Centre, Al-Husn College and Al-Karak College. The sample of the study consisted of (375) respondents representing (2.8\%) of the population of the study. Table (1) shows the distribution of the sample of the study according to the variables of the study.

Table 1. Distribution of sample of study according to variables (gender, type of college, academic year)

\begin{tabular}{|c|c|c|c|}
\hline Categories & Variables & Freq. & Percent \\
\hline Male & \multirow{2}{*}{ Gender } & 181 & $\% 48$ \\
\hline Female & & 194 & $\% 52$ \\
\hline Scientific & \multirow{2}{*}{ College } & 178 & $\% 47$ \\
\hline Human & & 197 & $\% 53$ \\
\hline First year & \multirow{4}{*}{ Major } & 82 & $\% 22$ \\
\hline Second year & & 86 & $\% 23$ \\
\hline Third year & & 92 & $\% 25$ \\
\hline Fourth year & & 115 & $\% 30$ \\
\hline \multicolumn{2}{|c|}{ Total } & 375 & $\% 100$ \\
\hline
\end{tabular}

\subsection{Tool of the study}

The questionnaire, the tool of the study, consisted of two parts; the first one includes the tool, its goal, and information about the respondents, while the other part includes (37) items measuring the university's role in promoting its students' social awareness from the 
perspective of the students themselves. This questionnaire was developed by reviewing the related previous literature. The initial tool consisted of (40) items distributed into three fields: university management, curricula, methods of teaching and evaluation and academic staff's member. The tool was presented to a group of arbitrators in the public Jordanian universities selected purposefully, in order to express their views towards the suitability of the items and the tool as a whole. These views were taken into consideration; some items were deleted, and other items were modified. The tool was, finally, consisted of (37) items, and also the tool's validity was confirmed to check the tool's degree of reliability, Cronbach's alpha for internal consistency was used, and the results showed acceptable reliability for all the fields. Cronbach's alpha value for the tool as a whole was (0.88) and table (2) illustrates this:

Table 2. Cronbach's alpha for internal consistency of all fields \& the tool as a whole

\begin{tabular}{lc}
\hline Field & Internal consistency \\
\hline University management & 0.88 \\
curricula\& methods of teaching and evaluation & 0.86 \\
Academic staff's member & 0.89 \\
Tool as a whole & 0.88 \\
\hline
\end{tabular}

\subsection{Statistical treatment}

The valid number of questionnaires for statistical analysis was (375). Degrees of the questionnaire's items were extracted by giving every item a digital estimated scale consisting of five degrees: agree with a very high degree $(5 \mathrm{~m})$, agree with a high degree $(4 \mathrm{~m})$, agree with a moderate degree (3), agree with a low degree (2) and agree with a very low degree (1). The researcher depended on the following standard values: means from (4.2-5) very high degree, from (3.4-4.1) very high, from (2.6-3.3) moderate degree, from (1.8-2.5) low degree and less than 1.8 is considered very low degree. Data were collected and analyzed statistically using (SPSS).

\section{Results \& Discussion}

10.1 Results concerning the first question: "What is the university's role in promoting its students' social awareness content from the perspective of the students themselves at Balqa Applied University?

To answer this question, means and standard deviations of the total degree on the subfields of university's role in promoting its students' social awareness content, from the perspective of the students themselves at Balqa Applied University, as it illustrated in table (3). 


\section{Macrothink}

Table 3. Means \& standard deviation of total degree of university's role in promoting the social awareness' content

\begin{tabular}{lrrc}
\hline Field & Mean & Std & Role's level \\
\hline University management & 2.67 & .26 & Moderate \\
Curricula \& methods of teaching \& evaluation & 3.29 & .56 & Moderate \\
Academic staff's member & 3.47 & .56 & High \\
Total & 3.14 & .38 & Moderate \\
\hline
\end{tabular}

It is clear from table (3) that the mean of the total degree of the university's role in promoting its students' social awareness content, from the perspective of the students themselves at Balqa Applied University, was (3.14) with a moderate degree. And the mean of university management was (2.67) with a moderate degree, and the mean of curricula and methods of teaching and evaluation's role was (3.29) with a moderate degree. However, the mean of the academic staff member's role was (3.47) with a high degree. To identify the university's role in promoting the social awareness' content in every sub field, the means and the standard deviations of the items of every field were calculated as it illustrated in tables $(4,5$ and 6$)$.

Table 4. Means \&standard deviation of items of university management's rolein promoting the social awareness content

\begin{tabular}{|c|c|c|c|c|}
\hline $\mathrm{N}$ of item & Item & Mean & Std & Role's level \\
\hline 4 & University provides health care to its students & 4.00 & .53 & High \\
\hline 12 & $\begin{array}{l}\text { The university encourages members of academic } \\
\text { staff to search in the social issues. }\end{array}$ & 3.52 & .94 & High \\
\hline 8 & $\begin{array}{l}\text { The university finance studies and researches } \\
\text { that help in developing the society with the } \\
\text { students' help. }\end{array}$ & 3.33 & .71 & Moderate \\
\hline 9 & $\begin{array}{l}\text { University organizes a number of social } \\
\text { activities, and provides enough time to practice } \\
\text { them. }\end{array}$ & 3.17 & .73 & Moderate \\
\hline 7 & $\begin{array}{l}\text { University supports the activities that assured the } \\
\text { freed of speech, thinking and constructive } \\
\text { criticism. }\end{array}$ & 3.15 & .55 & Moderate \\
\hline 1 & $\begin{array}{l}\text { Universities aware its students of the social } \\
\text { problems in the society, and prepare them to face } \\
\text { these problems. }\end{array}$ & 3.09 & .53 & Moderate \\
\hline 6 & $\begin{array}{l}\text { Educate students of their rights and duties in all } \\
\text { fields and aspects of life. }\end{array}$ & 3.01 & .45 & Moderate \\
\hline 5 & $\begin{array}{l}\text { Educate students of the importance of the } \\
\text { political participation, and encourage them to }\end{array}$ & 2.57 & .60 & Low \\
\hline
\end{tabular}


practice it.

2 Put \& discuss the solutions of the most significant social problems.

Low

The university guides the students' research to participate in solving the society's problems.

Very low

It shows the students their role in dealing with political problems of the society.

Very low

To limit the university violence phenomena inside university campus.

Very low

It is clear from table (4) that the best role of the university management in promoting its students' social awareness content was represented by the item (4): "the university provides health care to its student", where its mean was (4.00) with a high degree, and this may be attributed to the universities' care, including Balqa Applied University, of providing distinguished health system, and of giving much more attention to the health programs and services; where every university student gets benefit of all the health services which the medical clinics provide in the universities, and in the government hospitals. Item (3): "Reduce Violence University at the university campus", has got the least mean (1.25) with a very low degree, and this can be attributed to the students' feeling that university violence has become a phenomenon, that existed almost in all the Jordanian universities although of the parties' anger. And this result may also be attributed to the university management's policy in ignoring the students, and prohibiting the political and party activities inside the universities, and restricting the students freedom of work, and that what make the students to fill their free time making troubles. As a result, studying in the branches of Balqa Applied University will be stopped, because of this violence and no procedures to prevent such phenomena were taken. So, this result assured that the university administration' role was very low in preventing university violence phenomena.

Table 5. Means \&standard deviation of items of curricula \& methods of teaching \& evaluation's role in promoting the social awareness content

\begin{tabular}{|c|c|c|c|c|}
\hline $\mathrm{N}$ of item & Item & Mean & Std & Role's level \\
\hline 13 & $\begin{array}{l}\text { University encourages members of academic } \\
\text { staff to search in the social issues. }\end{array}$ & 4.10 & .55 & High \\
\hline 18 & $\begin{array}{l}\text { Methods of teaching used in university create } \\
\text { social interaction between the students and the } \\
\text { academic staff's member. }\end{array}$ & 3.48 & 1.04 & High \\
\hline 24 & $\begin{array}{l}\text { Evaluation tools used diagnose the students' } \\
\text { points of weakness \& strength. }\end{array}$ & 3.47 & 1.07 & High \\
\hline 16 & $\begin{array}{l}\text { The curricula suit the students' cultural, social } \\
\text { and behavioural attitudes. }\end{array}$ & 3.46 & 1.81 & High \\
\hline
\end{tabular}


25

23

15

17

14

20

21

19

26

27

22 ability of analyzing and criticising issues of

Evaluation tools in university promote the academic staff's members' vision to the students' skills.

$3.45 \quad 1.07 \quad$ High

Tools of evaluation in the university encourage the free competition between the students

$3.42 \quad 1.03 \quad$ High

The curricula instil the ethic and social values in the students' character.

$3.40 \quad 1.06 \quad$ High

The curricula link between originality and the contemporary, and keep Arab-Islamic identity.

$3.40 \quad 1.08 \quad$ High

The curricula develop the students' skills of

4 thinking, creating and analyzing.

$3.35 \quad 1.02 \quad$ Moderate

Methods of teaching followed in the $\begin{aligned} & \text { university develop } \\ & \text { techniques. }\end{aligned}$
Shura \& democracy $3.32 \quad .70 \quad$ Moderate

Methods of teaching followed in the university develop the students' ability of expression and speaking, and develop self dimension.

Methods of teaching followed in the university depend on dialogue, discussion and problems -solving.

$3.17 \quad .56 \quad$ High

Tools of evaluation help in predicting the students' performance in future.

$3.28 \quad .70 \quad$ Moderate

Tools of evaluation measure the students' ability of thinking, and analysis not their ability of memorizing.

.62 Moderate

Methods of teaching develop the students' the society.

$3.01 \quad .48 \quad$ Moderate

$2.55 \quad .78 \quad$ Moferate

It is clear from table (5) that the best role of the field of curricula and methods of teaching and evaluation in enforcing the students' social awareness was represented by item (13): "encourage academic staff's members to search in the social issues," where its mean was (4.10) with a high degree. The researcher believed that this result is totally logic, and anyone who browses instructions and rules of promotion process at Balqa Applied University feels the university's concern of motivating the academic staff's members; to search in the social issues, and link the academic staff's research efforts with the social requirements, and find 
solutions to these problems. So, this item has the highest mean with a high degree. And item (22): "Methods of teaching develop the student's ability of analysis and criticism to the society's cases," has the lowest mean where the mean was (2.55) with a very low degree, and this may attribute to the students' belief that methods of teaching are still provided to them in a traditional way depending on lecturing strategy, and the academic staff's members are no longer depend on analysis and criticism to the society's issues and other issues as well.

Table 6. Means and standard deviations of the items of the academic staff's role in promoting the social awareness content

\begin{tabular}{|c|c|c|c|c|}
\hline Role's level & Std & Mean & Item & $\begin{array}{l}\text { N of } \\
\text { item }\end{array}$ \\
\hline High & .55 & 4.15 & $\begin{array}{l}\text { Academic staff's member presents } \\
\text { example from social status during the } \\
\text { lectures. }\end{array}$ & 28 \\
\hline High & .71 & 4.10 & $\begin{array}{l}\text { Academic staff's member cares of } \\
\text { searching in the social status to identify } \\
\text { the problems, and look for solutions. }\end{array}$ & 32 \\
\hline High & .79 & 4.00 & $\begin{array}{l}\text { He helps the students to understand their } \\
\text { social status. }\end{array}$ & 29 \\
\hline High & 1.13 & 3.51 & $\begin{array}{l}\text { He allows the students to express their } \\
\text { opinions concerning scientific material } \\
\text { that is presented to them. }\end{array}$ & 37 \\
\hline High & 1.07 & 3.45 & $\begin{array}{l}\text { He allows the students to discuss the } \\
\text { social issues and the society's problems } \\
\text { with all of its types. }\end{array}$ & 31 \\
\hline High & 1.09 & 3.43 & $\begin{array}{l}\text { He helps the students to overcome his } \\
\text { Psychological problems. }\end{array}$ & 34 \\
\hline Moderate & 1.08 & 3.38 & $\begin{array}{l}\text { He helps in guiding the students towards } \\
\text { better future. }\end{array}$ & 33 \\
\hline Moderate & 1.08 & 3.38 & $\begin{array}{l}\text { He provides sufficient and correct } \\
\text { information about their social status. }\end{array}$ & 30 \\
\hline Moderate & .96 & 2.75 & $\begin{array}{l}\text { He helps the students to overcome their } \\
\text { social problems. }\end{array}$ & 35 \\
\hline Low & .77 & 2.55 & $\begin{array}{l}\text { He shared the students in all different } \\
\text { university activities and programs. }\end{array}$ & 36 \\
\hline
\end{tabular}

Table (6) showed that the best role to the academic staff's member in enhancing the students' social awareness content was represented in item (28): "the academic staff's member presents examples from the social reality in their lectures," while its mean was (4.15) with a high degree, and this may due to the students and academic staff's belief in Balqa Applied University that it is no longer acceptable to ignore the social status, therefore, they are obliged to discuss this reality by giving examples. This result assured the academic staff's concern of employing knowledge, and linking it with reality, so, this item obtained the 
highest mean with a high degree. While, item (36): “the students participate in university's activities and programs," has got the lowest mean (2.55) with a very low degree. This result seems logic if we know that it is rarely an academic staff's member shares the students the university's activities and programs, so, these members have no role in guiding these activities. Therefore, these activities could not achieve its objectives

2.10 Results of the second question: "Does the university's role vary in enforcing the students' content of the social awareness according to the variables of the study: gender, major and academic year?

To answer this question, the means and standard deviations were calculated, and $\mathrm{T}$ test for independent samples, To reveal the differences according to the variables of the study: (gender, type of college and the student's academic level), as it illustrated in tables (7, 8, and 9) is by using one way which is ANOVA.

\section{First: gender}

To answer this question, $\mathrm{T}$ test for independent sample was used to identify the difference in the university's role in enforcing the students' social awareness according to the gender variable, as it is illustrated in table (7).

Table 7. Results of $\mathrm{T}$ test for independent samples to examine differences in means of the university's role promoting the social awareness in light of the gender variable

\begin{tabular}{cccccccc}
\hline & & & & & F & Siq. \\
Fields & Gender & $\mathrm{N}$ & Mean & Std & T value & degree & \\
\hline $\begin{array}{c}\text { University } \\
\text { management }\end{array}$ & Males & 181 & 2.69 & .27 & 1.33 & 373 & .18 \\
& Females & 194 & 2.65 & .24 & & & \\
Curricula \& & Memale & 181 & 2.70 & .28 & 1.35 & 373 & .19 \\
$\begin{array}{c}\text { methods of } \\
\text { education \& }\end{array}$ & & & & & & & \\
evaluative & & 194 & 2.73 & .29 & & & \\
Academic & males & 181 & 2.68 & .37 & 1.32 & 373 & .17 \\
staff & Females & & & & & & \\
members & & 194 & 2.64 & .39 & & & \\
Total & Males & 181 & 2.69 & .24 & 1.34 & 373 & .18 \\
& Females & 194 & 2.67 & .26 & & & \\
\hline
\end{tabular}

It is clear from (7) that there were no statically significant differences at the level of significance $(\alpha=0.05)$ attributed to gender variable in all the fields of the questionnaire, and the tool as whole in promoting the students' social awareness. This indicates male and female views' convergence in all the field of the questionnaire. And this may attribute to the students' equivalence regardless of their gender in everything, presented to them as activities 
and teaching. Therefore, the role of the university's administration, curricula \& methods of teaching, and the academic staff's members in promoting the social awareness content was the same for both sexes.

\section{Second: Type of College}

To answer this question, $\mathrm{T}$ test for independent samples was used to examine differences in the role of university in promoting the students' social awareness content according type of college variable, as it illustrated in table (8).

Table 8. $T$ test for independent samples was used to examine differences in the means of the role of university in promoting the students' social awareness content according to type of college variable

\begin{tabular}{|c|c|c|c|c|c|c|c|}
\hline Fields & College & $\mathbf{N}$ & Mean & Std & $\begin{array}{c}\text { T } \\
\text { value }\end{array}$ & $\begin{array}{c}\text { F } \\
\text { degree }\end{array}$ & Siq . \\
\hline \multirow{2}{*}{$\begin{array}{l}\text { University } \\
\text { management }\end{array}$} & \multirow{2}{*}{$\begin{array}{l}\text { Scientific } \\
\text { Human }\end{array}$} & 178 & 2.65 & .27 & \multirow[t]{2}{*}{-1.64} & \multirow[t]{2}{*}{373} & \multirow[t]{2}{*}{.10} \\
\hline & & 197 & 2.69 & .25 & & & \\
\hline \multirow{2}{*}{$\begin{array}{l}\text { Curricula\& } \\
\text { methods of } \\
\text { education } \\
\text { \&evaluative }\end{array}$} & \multirow{2}{*}{$\begin{array}{l}\text { Scientific } \\
\text { Human }\end{array}$} & 178 & 3.32 & .50 & \multirow[t]{2}{*}{.88} & \multirow[t]{2}{*}{373} & \multirow[t]{2}{*}{.37} \\
\hline & & 197 & 3.27 & .61 & & & \\
\hline \multirow{2}{*}{$\begin{array}{l}\text { Academic } \\
\text { staff } \\
\text { members }\end{array}$} & \multirow{2}{*}{$\begin{array}{l}\text { Scientific } \\
\text { Human }\end{array}$} & 178 & 3.49 & .50 & \multirow[t]{2}{*}{.62} & \multirow[t]{2}{*}{373} & \multirow[t]{2}{*}{.53} \\
\hline & & 197 & 3.45 & .61 & & & \\
\hline \multirow[t]{2}{*}{ Total } & Scientific & 178 & 3.15 & .35 & \multirow[t]{2}{*}{.41} & \multirow[t]{2}{*}{373} & \multirow[t]{2}{*}{.68} \\
\hline & Human & 197 & 3.13 & .42 & & & \\
\hline
\end{tabular}

It is clear from table (8) that there were no statically significant differences at the level of significance $(\alpha=0.05)$ in the universities' role in promoting the students' social awareness content attributed to the type of the college variable in all the fields of the questionnaire, and the questionnaire as total. This shows the close between the human and scientific colleges' students' point of views in the role of the university in enforcing its students' social awareness. And this may attribute to the activities which university management organized as well as methods of teaching and evaluation. The academic staff's members' role in enforcing the social awareness content was the same in all the types of colleges, and there was no distinction in this field between the colleges.

\section{Third: academic year}

To answer this question, the means and the standard deviation to the universities' role in enforcing the students' social awareness content according to the academic year were calculated, as it illustrated in table (9). 


\section{Mll Macrothink}

Table 9. Means \& standard deviations for the total degree and subfields of the questionnaire of the university's role in promoting the social awareness' content according to the academic year variable

\begin{tabular}{llccc}
\hline Field & Level & N & Mean & Std \\
\hline University management & First & 82 & 2.70 & .28 \\
& Second & 86 & 2.68 & .30 \\
& Third & 92 & 2.60 & .21 \\
& fourth & 115 & 2.69 & .23 \\
& Total & 375 & 2.67 & .26 \\
Curricula \&methods of & First & 82 & 3.27 & .43 \\
teaching \& evaluation & Second & 86 & 3.17 & .62 \\
& Third & 92 & 3.33 & .63 \\
& Fourth & 115 & 3.36 & .54 \\
Academic staff member & Total & 375 & 3.29 & .56 \\
& First & 82 & 3.47 & .44 \\
& Second & 86 & 3.27 & .59 \\
& Third & 92 & 3.50 & .62 \\
& Fourth & 115 & 3.59 & .53 \\
& Total & 375 & 3.47 & .56 \\
& First & 82 & 3.14 & .30 \\
& Second & 86 & 3.04 & .43 \\
& Third & 92 & 3.14 & .42 \\
& Fourth & 115 & 3.21 & .36 \\
& Total & 375 & 3.14 & .38 \\
\hline
\end{tabular}

It is clear from table (9) that there were apparent differences between the means in the university's role in promoting the students' social awareness' content in all the fields of the questionnaire, and the total degree according to the student's academic year variable. And to know if these variables are statistically significant at the level of significance $(\alpha=0.05)$, ONE WAY-ANOVA was used as it illustrated in table (10).

Table 10. Results of one way ANOVA to the means of the total and sub degrees of the questionnaire of the university's role in promoting the social awareness content

\begin{tabular}{|c|c|c|c|c|c|c|}
\hline Field & Source of variance & $\begin{array}{l}\text { Sum of } \\
\text { seq. }\end{array}$ & $\begin{array}{l}\text { F } \\
\text { degree }\end{array}$ & $\begin{array}{l}\text { Mean of } \\
\text { seq }\end{array}$ & F value & Siq. \\
\hline \multirow{3}{*}{$\begin{array}{l}\text { University } \\
\text { management }\end{array}$} & Between groups & .60 & 3 & .20 & 2.98 & .031 \\
\hline & Within groups & 25.07 & 371 & .068 & & \\
\hline & Total & 25.67 & 374 & & & \\
\hline \multirow{3}{*}{$\begin{array}{l}\text { Curricula } \\
\text { \&methods } \\
\text { teaching } \\
\text { \&evaluation }\end{array}$} & Between groups & 2.11 & 3 & .70 & 2.19 & .088 \\
\hline & Within groups & 119.01 & 371 & .32 & & \\
\hline & Total & 121.13 & 374 & & & \\
\hline Academic & Between groups & 5.3 & 3 & 1.77 & 5.71 & .001 \\
\hline
\end{tabular}




\begin{tabular}{llccccc}
\hline member & Within groups & 114.86 & 371 & .31 & & \\
& Total & 120.17 & 374 & & & \\
Total degree & Between groups & 1.42 & 3 & .47 & 3.18 & .024 \\
& Within groups & 55.18 & 371 & .14 & & \\
& Total & 56.60 & 374 & & & \\
\hline
\end{tabular}

It is clear from table (10) that there are statistical significant differences at the level of significance $(\alpha=0.05)$ in the role of the university in promoting the students' social awareness content, in the fields of university management, and the academic staff's member, and the total degree. Whereas there are no statistical significant differences at the level of significance $(\alpha=0.05)$ in the role of curricula, and methods of teaching and evaluation attributed to the student's academic level. And to reveal the sources of these differences, Scheffe Post Hoc Comparisons Test was used as it illustrated in table (11).

Table 11. Results of Scheffe test to examine differences between the means of degrees on fields of the role of university administration \& academic staff's member, and the total degree in promoting the social content according to the student's academic level.

\begin{tabular}{cccccc}
\hline Field & Year level & Mean & Second & Third & Fourth \\
\hline University & First & 2.70 & .01 & $.10\left(^{*}\right)$ & .00 \\
management & Second & 2.68 & & .08 & -.00 \\
& Third & 2.60 & & & -.09 \\
& Fourth & 2.69 & & & \\
Academic staff & First & 3.47 & .20 & -.02 & -.12 \\
& Second & 3.27 & & -.22 & $-.32\left(^{*}\right)$ \\
& Third & 3.50 & & & -.09 \\
Total degree & Fourth & 3.59 & & & \\
& First & 3.14 & .10 & -.00 & -.06 \\
& Second & 3.04 & & -.10 & $-.16\left(^{*}\right)$ \\
& Third & 3.14 & & & -.06 \\
& Fourth & 3.21 & & & \\
\hline
\end{tabular}

\section{* Significance at $(\alpha=0.05)$}

It is clear from table (11) that the difference between the means of the university's role in enforcing the social awareness from the perspective of the first - year students, and between the mean of the second - year student was (0.10). And it is statistically significant at the level of significance $(\alpha=0.05)$ in favor of the first year students, and the other differences in this field were not statistically significant at the level of significance $(\alpha=0.05)$. This indicates that the university's role in enforcing students' social awareness content was higher from the first year students' perspective, and this shows a logical result from the researcher's perspective, because the first year students are more affected by the university atmosphere with its components. And the first year students interacted more with the university's administration by following up the university activities and programs. So, the influence of the field of university administration in promoting the students' social awareness was statistically significant in favor of the first year students. 
And it is clear from table (11) that the difference between the means of the academic staff's member's role in promoting the social awareness content was (0.-32). And it is statistically significant at the level of significance $(\alpha=0.05)$, and the differences were in favor of the students of the fourth year. It is also clear from table (11) that the difference between the means of the university's role in enforcing the students' social awareness in the total degree, and from the perspective of the students of second and fourth year was (0.-16). And it was statistically significant at the level of significance, and in favor of the fourth year students, while other differences in different means of the total degree were not statistically significant at the level of significance $(\alpha=0.05)$. And this shows that the university's role in promoting the students' social awareness, in general, was higher from the perspective of the fourth year student, and this could be attributed to the fourth year students' relation with their teachers which is mainly considered strong, especially if it is compared with students' relation in the first years with their teachers. And because of this relationship, they are more affected by their teachers, and the academic members are more communicated with them, therefore, they are more capable to aware them socially. The fourth year - students know much about the university's social programs and activities that help in promoting the students social awareness.

\section{Recommendations}

1. Re-search in the activities of developing the students' social awareness which are university administration, curriculum, evaluation and the academic staff, and their role in developing the students' social awareness, university activities, programs, conferences and all university's facilities that help in developing the university students' social awareness.

2. To reconsider the students' common courses to enrich the students' knowledge in the fields of human, social, scientific and cultural knowledge, and to evaluate, update and develop these courses from one time to another to suit the students' social status.

3. To conduct further studies that addressed social awareness of other categories in the Jordanian society with other variables.

4. To activate the youth forums and utilize their free times through cultural, educational and cultural programs, on order to meet the youth needs.

5. To prepare programs aim to deal directly with the youth, so as to strengthen their loyalty towards the society, and to increase their productivity, and to invest their capabilities. 


\section{References}

Al-Asa'd, Mohammad Mustafa (2011). Problems of University Youth and Challenges of Development. Beirut: university institution of studies.

Al-Haj, Kameel (2000). Al-Mawsoa`Al-Moysara in the Social Philosophical Thought. Beirut: Lebanon Library.

Al-Hawamda, Kamal (2005). Effects and Alienation Aspects in the Jordanian Universities. Al-RAI Newspaper (12694) 23/6/2005.

Al-Hussami, Mohammad Miflih Falah (2010). The degree of the University of Jordan's commitment to the promotion of human rights concepts from the student's perspective. Unpublished Dissertation, Amman, Jordan.

Amin, Abeer Farid (2008). Religious awareness of Egyptian Youth, Field study of a sample of universities' students. Publications of Cairo University: Egypt.

Jassim, Mohammad (2005). Health Culture and Health Awareness. Journal of Health Education, Ain Shams University: Egypt.

Abdel Latif, Abdul Basit (2004). Education \& counterfeiting social awareness, a study of exploring the content of some Egyptian curricula in Egypt. Journal of Social Sciences, $132,28-40$.

Abdel Latif, Nidal. (2005). Social Services. Arab Society Library: Amman, Jordan.

Abdel Wahab, Laila. (2003). Effect of religious trends in the Arab Women social awareness. Journal of Mostaqbal, 12(132), 28-40.

Al-Hafni, Abdel Moneim (2010). The Comprehensive lexicon for idioms of philosophy (ed.). 4, Cairo: Madboli Library.

Al-Rashdan, Abdullah (2004). Sociology of education. Amman: Dar El-Shrouq.

Al-sheikh, Omar \& Sleibi, Jihad (1996). Role of University of Jordan in developing its students' Modernity attitudes. Journal of social sciences, 14(4), 175-208.

Al-Tai, Nizar Mahdi (2002). Attitude towards religion and its relation with some personal facts at a sample of university students in Kuwait. Annual of the Faculty of Arts and Social Sciences, (12), 39-60.

Tantawi, Hassan Ibrahim (2006). Education and development Problem. Book of Nation, Qatar, 89, 17-38.

Christine, D., \& Smith, John (2010). Teaching Social Skills. Tori Dangles, 3(5), 258-271.

Kathlyn, M (2011). Social Skills and Academic Achievement. Evidence for Education, IIII(2), 312-328.

Lewis, L (2007). Faculty and the Students A Profile. College and Student. New York: Paragon Press. 
Lodge, A (2003). What Do Students Feel about The Current Education System? The Hindu online Edition of India's Nation News Paper. Saturday, Dec, 13.

Makrom, Abdel Wadod (2009). Role of University in developing the youth responsibility in the national responsibilities to support development issues and building future of Egypt. Centre of values \& in university of Mansoura: Egypt.

Marianna, C (2002). Social Awareness Skills for children. Jessica Kinsley. Publishers: United Kingdom.

Nasser, Ibrahim (2004). Human Awareness - Education foundations. Amman: Al-Raed Library.

Nizar, Hamou (2005). Youth Needs between Society Awareness \& Development. Al-Rai University $N$ 12617, 7/4/2005.

Prasovlova, E. (2002). Supporting Awareness in Education. Manchester Publishers: UK.

Rianna, C (2008). Social Awareness Skills for Higher Education. Higher Education, 14, 149.

Salim, Ali (1999). Awareness between individual and the group - Awareness and Practice. Journal of Modern Arab Thought, (74-75), 71-83.

Watfa, Ali Asad (2001). Social \& political challenges in Kuwait and Arab World. Publications of University of Kuwait: Kuwait.

Zeitoon, Aish (1995). University Teaching Methods. Amman, Dar El-Shrouq.

\section{Copyright Disclaimer}

Copyright for this article is retained by the author(s), with first publication rights granted to the journal.

This is an open-access article distributed under the terms and conditions of the Creative Commons Attribution license (http://creativecommons.org/licenses/by/3.0/). 